\title{
correspondence
}

\section{Detecting dead bodies in 1718 and 1976}

SIR,-I reported (Nature 262, 816 (1976)) that dead bodies of a dog and a cat were detected by the presence of fruit-bodics of an agaric species (Hebeloma vinosophyllum) appearing on the ground above the buried bones, and suggested the possibility that a victim of homicide buried in soil could be located by this or similar fungi. In response to a 'Science report' in The Times (2 September 1976) summarising my article, Dr Denys W. Tucker, formerly of British Museum (Natural History), informed me of a passage published in 1718, (Aubrey, J. The Natural History and Antiquities of the County of Surrey 111, (E. Curll, London 1918) ), which contains the following lines (pages 225-26) written by John Aubrey of his visit to Woking in Surrey.

"The Grave-Digger here told me, that he had a Rulc from his Father, to know when not to dig a Grave upon a Corps not rotted; which was, when he found a certain Plant about the Bigness of the Middle of a Tobacco-Pipe, which came near the Surface of the Earth, but never appear'd above it. It is very tough, and about a Yard long; the Rind of it is almost black, and tender, so that, when you pluck it, it slips off, and underneath is red; it hath a small Button at Top, not much unlike the Top of an Asparagus: Of these sometimes he finds two or three in a Grave. He is sure it is not a Fern Root.
He hath with Diligence trac'd to its Root, and finds it to spring from the Putrefaction of the dead Body. ."

The phenomenon described here is close to what I suggested, but is not exactly the same as that expected of ammonia fungi including the abovementioned species (Sagara, N. Contr. biol. Lab. Kyoto Univ. 24, 205-276 (1975)). "It" reminds us of the rhizomorph, pseudorhiza, or aborted fruitbody produced by certain fungi, but does not fit those of any known ammonia fungi. Fiurther, if we interpret "the Putrefaction of the dead Body" as putrefying corpse, the ammonia fungi would not appear at such an early stage of decomposition.

I have becn discussing the matter with some noted mycologists and botanists from the UK and Japan, but so far we have not succeeded in pointing out any possible organism for the structure described by J. Aubrey. I would appreciate receiving suggestions as to what it might be and any similar information from any part of the world.

I thank Dr Tucker for the information, and Drs Roy Watling, Geoffrey C. Ainsworth, Rokuya Imazeki, Siro Kitamura, Osamu Sinoda, and Minoru Hamada for the discussion. Yours faithfully,

NAOHIKo SAgara

Biological Laboratory,

Yoshida College,

Kyoto University, Japan

\section{The twin paradox}

SIR,-Tom Wilkie's remark (28 July, page 295) that the resolution of the twin paradox lies in the fact that the equivalence of the twins is destroyed by the necessity for the 'moving' one to reverse his motion continues to ignore the fact, pointed out in my letter in Nature of 31 August, 1973, that, if that were so, the equivalence would be maintained during the first half of the journey, before reversal occurs. Hence, in the example there cited, Paul, the 'moving' twin, would reach the distant planet a teenage boy, and the reversal and return would restore him to babyhood. It is not customary in scientific research to ignore such obviously remarkable and important points. Will Mr Wilkie therefore kindly say whether he accepts this recessary consequence of his suggested resolution of the paradox, or agrees with me that it makes such a resolution impossible?

Yours faithfully,

Herbert Dingle

\section{Hull, UK}

Tom Wilkie replies: I stand by every word of my article and do not accept that the above is a necessary consequence. I am writing to Professor Dingle privately on this matter.

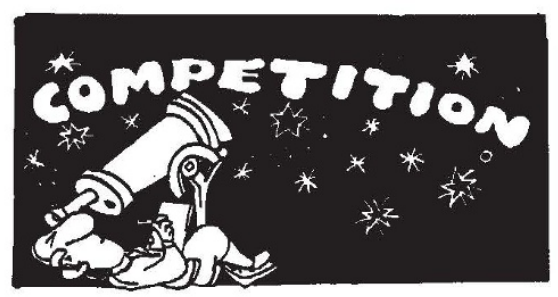

Competition 14 asked for a boring or meaningless paragraph. $£ 10$ to E. R. A. Beck of Vienna for these introductory remarks:

The subject to be considered in this session of the symposium is one on which much research has been done, much grey matter has been activated and much fruitful discussion has alrcady taken place. Its importance is well known to all of us here today, whether we face it at the laboratory bench or at an adminis- trative, policy-making or governmental level. Indeed, the fact that an international organisation has chosen to devote an afternoon to an cxchange of information on this topic is sufficient evidence that interest has transcended national boundaries. In some form or other, it affects the developed and the developing countries, the technologically advanced and the less-advanced peoples. There is, as yet, no consensus on a solution, nor indeed on a programme for the coming period. In my talk, therefore, I shall attempt to focus attention on some of the more significant points, and express some humble thoughts of my own as to how we might, together, approach the task of secking a methodology for tackling this absorbing question, ensuring as we do so that our endeavours will also serve those facing this problem in the nations less wel endowed with trained manpower and sophisticated equipment. (Aside, speaker to chairman: "I say, which symposium is this: 'Advanced techniques in control of the screw-worm fly', or 'Special constraints in seeding methods for MHD generators?')

Honorable mention to J. R. Richards (Tadcaster, North Yorkshire) for a genuine paragraph from The Mind of Light by Sri Aurobindo.

Competition 15. The front cover of Nature used to carry a quotation from Wordsworth:

'To the solid ground

Of nature trusts the Mind that builds for aye'.

$£ 10$ for the best quotation or verse, serious or humorous, suitable for these days. Entries to Competition 15, Nature, 4 Little Fssex Street, London WC 2 by October 20 . 